\title{
Sociological Research on Higher Education in English Canada 1970-1980: A Thematic Review*
}

\author{
ROBERT M. PIKE†
}

\begin{abstract}
Sociological research on higher education in Canada is in an infancy state at best. However, this article explores some main ideological and empirical themes which are emerging in the relevant sociological literature on higher education in English Canada, concentrating primarily on the growing number of studies dealing with inequality of access to education beyond the high school, and particularly the search for the sources of inequality in socioeconomic status, region and sex. Some attention is also given to the limited body of sociological research on higher education organizations, on student attitudes, values and behaviour, and on the academic profession in English Canada. The greater part of the English language literature is shown to emanate from Ontario and the major ideological thrust in this literature is noted as being a conflict perspective which emphasizes the role of conflict in the process of change within universities and colleges, and which perceives these institutions as agencies for the reinforcement of the status quo rather than for the moderation of existing social inequalities. Various suggestions are offered for future research priorities, emphasizing particularly the need for the employment of a developmental comparative perspective.
\end{abstract}

\section{RESUME}

La recherche sociologique traitant de l'enseignement supérieur au Canada est encore dans un état embryonnaire. Cet article explore les principaux thèmes idéologiques et empiriques en voie d'émergence dans la littérature produite par le Canada anglais et fait état du nombre croissant d'études ayant trait à l'accessibilité à l'enseignement postsecondaire et particulièrement aux sources d'inégalité reliées au statut socio-économiqut, la région et le sexe. L'auteur traite également de l'aspect sociologique des organisations en enseignement supérieur, des attitudes des étudiants, de même que de leurs valeurs et comportement et de la profession académique au Canada anglais. $L$ 'article indique que la majorité des études provient de l'Ontario et que la ligne directrice de ces études décèle les situations conflic-

\footnotetext{
* Revised version of paper presented at the Annual Meeting of the Canadian Society for the Study of
} Higher Education, Halifax, June 1981.

† Head of Department of Sociology, Queen's University. 
tuelles qui interviennent lorsque des changements s'opèrent dans les universités et collèges. Dans ce même contexte, les institutions sont perçues comme des agents de renforcement du statu quo plutôt que comme des catalystes visant à amoindrir les inégalités sociales existantes. Des suggestions sont offertes quant aux priorités de recherche et aux perspectives à envisager pour l'établissement de bases comparatives.

\section{INTRODUCTION}

In a paper published in 1973, American sociologist Burton Clark notes that it was not until the 1960's that one can discern a serious sociology of higher education in the sense of a sub-field with a steady flow of writing and a specialty in which students take training, pursue it for a number of years and accept a professional label (Clark, 1973: 5). Clark's comments were, however, written in the context of the sociological enterprise in the United States; and I would hesitate to suggest that we have yet reached the point in Canada where the sociology of higher education can be called "serious", at least in the manner in which he defines the sub-field's status south of the border. The sociology of education, the broader sub-field which concentrates upon the application of sociological approaches to the study of elementary, secondary, and higher education, was itself a pretty fragile enterprise in this country until the early 1970's; and even now most of those Anglo-Canadian sociologists who are interested in education tend to focus upon research in the elementary and secondary schools. Consequently, "sociologists of higher education" are rather rare birds in English Canada. One finds them scattered here and there in university departments of sociology, of education and in higher education research units. However, none to my knowledge have attained reputations for continuous research in the sub-field which would match those of Burton Clark and Martin Trow in the United States and A.H. Halsey in Britain.

According to Clark, the major focus of the sociology of higher education in the United States has rested on the study of inequality in education beyond the high school, particularly the search for the sources of inequality in social class, race, ethnicity and sex (op. cit.: 5 ). The same pattern of study is evident here, and explains why a large proportion of this paper is devoted to the theme of inequality and higher education. Beyond this root concern, the American literature has tended to focus upon the effects of college years on the character, belief and thought of students; upon the study of organizations of higher education, and upon higher education as a profession. However, whilst I have overviewed some of the English Canadian sociological literature in these areas of study also, it proved to be rather difficult here - given a paucity of relevant research material - to do much more than point the ways in which sociological research might well proceed from this point on. Up to the present, the study of inequality and higher education appears to have dominated the interests of most of those Anglophone sociologists who are interested in the post-secondary field.

Before turning to my actual review, I should make it explicit that I intend to concentrate upon Canadian sociological studies in higher education which are based either upon national data or upon research carried out within the predominantly Anglophone provinces. ${ }^{1}$ I am aware, of course, that there have been, and probably are still, some differences in the 
research interests and theoretical perspectives of those sociologists who have studied education in English Canada and in Quebec. For example, in 1976, the Albertan sociologist B.Y. Card noted that there was apparently far less interest in the sociology of education amongst sociologists and anthropologists in English Canada than in Quebec: an observation which he supported by evidence drawn from the 1970 Directory of Sociologists and Anthropologists in Canada (Connor and Curtis, 1970) which showed that whilst 1 in 7 Quebec sociologists and anthropologists listed the sociology of education as a specialization, the equivalent proportions were $1: 19$ in Ontario, $1: 17$ in the West and 1:71 in the Atlantic provinces (Card, 1976: 16-17). A somewhat more recent survey (Decore, 1977) based upon the 1973 Directory shows a considerable improvement in the proportions in English Canada with about 1 in 8 sociologists and anthropologists listing the sociology of education as a specialization - the same ratio as in Quebec. However, it is my impression that Quebec sociologists, partly perhaps because of the relatively close interlinkage between education and political ideology in the province but also because of the sense of an almost organic interconnection between educational change and profound social change elsewhere in the society which characterized Quebec during the "Quiet Revolution", are more likely than those in English Canada to give attention in their studies to the relationship of education to 'la societe globale': to the whole society of which the educational system is a part. I would suspect also that they tend to play a somewhat more influential role than their counterparts elsewhere in the process of educational policy-making. ${ }^{2}$

Finally, I should add that I have not hesitated to include under the rubric of sociology those relevant studies which have been carried out by scholars who would describe themselves as being in "educational administration", "institutional research" or whatever. Despite Burton Clark's definition of a "serious" sociology of higher education, an attempt to restrict this review only to a consideration of those English language studies which were carried out by professionally-trained sociologists - whether or not they carry an institutionally applied "higher education" speciality label - would have the effect of excluding quite a substantial part of the already limited research literature. On the other hand, however, since I have acted as "a one man band" in preparing the review, I am certain that there are studies and research themes which I have either overlooked or given scant attention. A couple of the neglected research themes are indeed mentioned in the conclusions to this paper.

\section{INEQUALITY AND HIGHER EDUCATION ${ }^{3}$}

\section{Sociological Perspectives on Change in Higher Education}

There are a number of theoretical approaches adopted, or preferred, by sociologists who study educational systems, but the two approaches which are the most relevant to an analysis of the interlinkages between higher education and inequality are entitled "functionalism" and "conflict theory". It is a general feature of functionalist theory to view society as consisting of a relatively stable and persistent structure of elements in which each element (for example, the educational system) has functions, i.e. contributes to the maintenance of the society as a whole. Given this characteristic, it is not surprising that functionalist writers have tended to concentrate upon the task of describing the perceived functions of the educational system in the society, and have usually considered major educational change - as in the case of the post-war expansion of the Canadian post-secondary systems 
- as occurring in response to the requirements of the polity and the economy for more highly educated citizens and workers. Conflict theory, on the other hand, tends to lay emphasis not upon social integration, cohesion and shared norms (a characteristic of the functionalist approach) but rather upon such features of social life as conflict, coercion and the struggle for scarce resources. In its major orientation, which is neo-Marxist, the main thread of argument is that the role of education in capitalist society is to assist in the intergenerational reproduction of the social division of labour associated with the capitalist economy. Thus, from this perspective, the expansion of post-secondary education is perceived as having been less a response to the needs of polity and economy than as a means whereby a "dominant" or capitalist class created the illusion of an increasingly open society for all social strata without actually seriously disturbing prevailing social inequalities in access to higher leaming.

A number of Canadian sociologists (for example, Lockhart 1975, Pike 1980) have analysed the theoretical props which supported the expansion of post-secondary education between the late 1950's and the early 1970's. One major theme of the 1960's amongst economists interested in education was that the expansion of higher education was desirable because it constituted an investment in "human capital". In essence, human capital theory was based upon the belief that, beyond a certain stage of economic development, further economic growth depended mainly upon technological innovation; and, in turn technological innovation, was seen to be a product of highly skilled and qualified "brain power". Put simply, increased numbers of educated people were linked to increased productivity, and this support provided by economic theory for post-secondary expansion was also to be seen at the level of family unit and individual, in the encouragement which it gave to Canadian parents and their children to invest more time and money in education. Most of them did so because such an investment was assumed to pay substantial dividends in the form of better occupations and higher incomes. The message of "investment in self" was, in fact, an integral part of human capital-productivity theory, and well-attuned to the traditional North American ideology of the "open society" with its wide opportunities for upward social mobility. Indeed, the liberal notion of equality of educational opportunity with its belief that all young people should be provided with an opportunity commensurate with their abilities irrespective of their origins, locality, sex and race was attractive to human capital theorists not simply on moral grounds, but because the failure to eliminate those barriers to educational achievement which arise from the inequalities of the wider social environment can be seen as an inefficient utilization of human resources: and hence as a possible barrier to the potential growth of G.N.P.

The merging of economic theory and liberal doctrine during the post-secondary expansion found support from sociological functionalists who were, at the time, dominant in American and English Canadian departments of sociology. Since many functionalist writers believe that social stratification - that is, differences in income, power and prestige between different social groups in the society - has a function of attracting the most ambitious and talented persons to the best-paid, most prestigious occupational positions, they could certainly support an economic doctrine (human capital) which in alliance with a moral concept (equality of educational opportunity), appeared to offer the prospect of an increasingly good fit between top jobs and top talents. Taken all together, therefore, these sets of theoretical perspectives exerted an almost irresistible pressure for educational expansion and reform. By hindsight, we know now that many of these prevailing arguments were flawed: that investment in human capital does not guarantee 
higher national productivity; that the economic returns to individual "investment in self" can fall; that ultimately many young people (or, more specifically, many young men) could decide that three or four years spent in higher education did not compensate adequately for earnings foregone. However, in the positive balance, the current stage of "mass" postsecondary education means that in many provinces, almost one-half of the young adult population have received some measure of exposure to education beyond the high school level.

\section{Socio-Economic Status and Post-Secondary Participation}

The advent of mass post-secondary education has tended to be associated with the notion of its democratization: namely, that the universities and colleges have been opened to substantially greater numbers of young people from most, or all, social strata in the society. This notion is most probably correct, but it offers a view of growing access to post-secondary education which is not likely to satisfy the analytically-minded sociologist (especially if he or she is inclined to a conflict perspective), because there still remains a crucial question: namely, was the expansion of post-secondary facilities accompanied by any significant reductions in those major differentials in social class and regional opportunities in access to these facilities which certainly characterized Canadian education during the 1950's (see Porter, 1965, Chapter VI, passim). This was one of the central questions which I attempted to answer in my report on access to undergraduate education which I wrote for the A.U.C.C. in 1970 (Pike, 1970). The conclusion which I came to at that time, albeit on the basis of limited evidence, was that there was no indication that the university expansion had been accompanied by more than a small increase in the participation rates of students of lower class origins relative to the participation of students from the more privileged classes. Subsequent research by Canadian sociologists such as Edward Harvey (1977a, 1977b) tends to be supportive of this conclusion, although there are clearly some substantial methodological difficulties in comparing the social characteristics of university populations over time. In other western countries, as American sociologist Christopher Hurn has recently shown (1978, Chapter 4, passim), the picture would appear to be generally similar: for example, in Britain, France and the United States, there is evidence that lower class youth have increased their chances of completing high school and going on to some kind of post-secondary education at a somewhat greater rate than children from more privileged backgrounds, but - to take the American case - a relatively higher proportion of the lower class students who now enter that country's post-secondary system appear to be destined for the junior or community colleges whereas the state universities, and the prestigious private institutions, continue to draw from predominantly middle and upper middle class populations (Hurn: 98). In any event, as Hurn notes, in Western European societies "there are huge differences in the proportion of children from different social origins who are successful in gaining admission to selective secondary schools and to institutions of higher education. And, while we do not have strictly comparable evidence from the United States, many studies of school attainment in this country demonstrate that such a generalization does not apply to Europe alone" (op. cit.: 94-95).

The above observations are, of course, very general in nature, but they do take account of those North American differences in the patterns of academic and social selection which distinguish between admission to universities on the one hand, and colleges of 
applied arts and technology on the other. Thus, in English Canada, there has been an accumulation of research evidence from many provinces during the past few years which indicates quite clearly that students who enter community colleges straight from high school are not only likely to have somewhat lower levels of educational attainment and academic standing than students who enter university, but they also tend to be attracted more evenly from a relatively broad social cross section of the population, while universities draw relatively heavily from middle and upper-middle class homes. (See, notably, Dennison, 1975; Anisef, 1981; Russell, 1977-78; Secretary of State, 1976; von ZurMuehlen, 1980). This evidence indicates, therefore, that the growth of the non-university post-secondary sector has provided new higher educational opportunities to substantial numbers of students of lower socio-economic status who would probably not otherwise have gone beyond high school. However, since the sector does tend to be less academically prestigious than the universities, attracts a somewhat larger proportion of lower class youth (and, as we shall see, women), and is, in some measure, preparing students for levels of the occupational hierarchy somewhat less prestigious than those occupational levels traditionally open to degree holders, the establishment and grow th of community colleges in both Canada and the U.S.A. has been interpreted by some radical sociologists as providing just one more mechanism for ensuring the intergenerational transmission of inequality and for meeting the evolving demands of the capitalist labour market (see Schechter, 1977, for Canada and Bowles and Gintis, 1976, for the U.S.A.). This view is largely a matter of ideological preference, although much of the sociological literature on patterns of access to higher learning does emphasize the need to avoid "trapping" high school students in academic programmes which might not enable them to qualify for university admission.

As a textual footnote to the above observations, I should mention that I have examined the socio-economic characteristics of Canadian full-time college and university students in some detail elsewhere (Pike, 1980). Suffice it, therefore, only to add here that the evidence that children from middle and upper-middle class families are greatly overrepresented amongst full-time university students should be qualified by the recognition that traditionally, and perhaps currently, a relatively larger proportion of the part-time undergraduate population has been of lower and lower-middle class origins (see notably, Pike, 1978). Another qualification, though less obvious, is that some account should be taken of regional patterns of inequality in access to higher learning which, in some measure, cut across the influence of social class factors. For example, in a recently published longitudinal Ontario study which commenced in 1973 and for six years followed the careers of a substantial sample of students enrolled in Grade 12 in that year, the researchers found that the proportions of the sample who obtained some post-secondary educational experience was 74 per cent for those living in a "big city", 67 per cent in "large cities" and "smaller cities" and 52 per cent of those living in "towns and rural areas" (Anisef, 1980: 110). Part of the reason for this urban:rural differential in post-secondary access could, as the researchers note, be explained by the fact that young people from the rural areas of Ontario were more likely to be of lower socio-economic status than those from the cities. However, there was a "double hardship" for rural students, for not only were they more likely to come from an economically disadvantaged family, but the desired post-secondary education, if it were to be obtained, more frequently required a move away from home, thereby involving an extra expense not required of most urban origin students. 


\section{Social Background, Higher Education and Occupational Selection}

The concluding observations above suggest a need to search for the causes of social and regional inequalities in access to higher learning. However, this is a theme we will consider at a later stage in the paper. A prior task is to move beyond the evidence of the existence of such inequalities in order to review some of the conclusions of those sociological studies which have attempted to isolate the impact of specific variables associated with selection in educational systems: for example, the impact of scholastic aptitude and the type of high school programme in which the student is enrolled. Furthermore, it is clearly important not to take for granted that a high positive correlation between social class background and chances of access to higher learning indicates, as many neo-Marxian writers would suggest, that the class structure simply 'self-recruits' from one generation to the next: that is, differences between various socio-economic groups in chances of going to university and college mean equivalent differences, through educational attainment, of reaching given levels in the occupational structure, and hence the class structure, of the society. One must, therefore, give some attention to the relationship between social background, level of educational attainment and occupational choice.

Ten years ago, the Canadian English-language literature on the above topics was very thin. I would not claim that we have yet reached the stage where we can be completely satisfied with what has been achieved in the interim, but certainly we do know much more now about the complex nature of the processes of academic and social selection which occur within educational systems and, to a lesser extent, about the linkage between socio-economic status, educational attainment and occupational structure. However, with the exception of Raymond Breton's monumental national study (researched during the 1960's but published in 1972) on Social and Academic Factors in the Career Decisions of Canadian Youth, one limiting feature of much of the relevant research is that it is Ontario-based and hence reflects the particular educational characteristics of that province (e.g. the continued existence of Grade 13 and the binary system of post-secondary education). Thus, one can point to the major study of the hopes and expectations for education and work of about 9,000 Ontario high school students, and 3,000 of their parents, which was carried out by Marion Porter, the late John Porter and Bernard Blishen in the early 1970's and subsequently published under the title of Does Money Matter? (revised edition, 1979). Then there is the previous-mentioned study of Paul Anisef and colleagues, which under the title Is the Die Cast? provides an almost unique longitudinal analysis of the progress of a cohort of Ontario Grade 12 students right through post-secondary education and into the workforce. Other relevant research would include John Buttrick's report to the Ontario Economic Council on Who Goes to University from Toronto? (1977), and Oswald Hall and Richard Carlton's study, also published by O.E.C., on Basic Skills at School and Work (1977). This concentration of relevant research in Ontario is, in goodly part, a reflection of the concentration of a large proportion of the Anglophone sociological community in the province, and also in some degree of the willingness of various Ontario government bodies to fund sociological research related to education and career choice. But whilst there have been some studies of a similar nature elsewhere - for example, the survey of the post-secondary plans, aspirations and profile characteristics of some 2,200 Grade 12 students in Manitoba carried out by C. Neil Russell, et. al. (1977-78) - there would clearly be much to be gained scholastically if detailed studies à la Porter and Anisef, which might allow for comparisons with the conclusions of the various Ontario studies, were to be carried out 
elsewhere in English Canada. Currently, there is some danger in simply extrapolating from the Ontario research to cover social and academic processes of selection, choice and attitude formation which may exist in other provinces and regions (e.g. the Atlantic provinces with their relatively low per capita incomes, strong rural traditions and limited employment opportunities).

I turn now to an overview of some of the major research conclusions of these and other studies. The overview is made in the form of a series of numbered sections, and attempts to trace the major social and intellectual factors influencing selection, choice and attitude formation at various stages of the educational system and entry to the workforce.

1. The concept of "equality of educational opportunity" points to an ideal state of society (probably unattainable) in which ascribed characteristics such as social class origins, race or gender play no part in influencing educational opportunities and choices. Presumably then, if such a "meritocratic state" were to be achieved, only native intelligence, scholastic aptitude and innate motivation would determine an individual's level of educational attainment. Currently, however, whilst mental ability and school performance do certainly play an important part in influencing educational choices at the high school and post-secondary admission stages, the available evidence suggests that ascribed factors notably, family background - play a part which is not much less important. For example, the Porter study found that, although there was a tendency for the most mentally able students also to be also drawn disproportionately from upper class homes (i.e. where the parents are well-educated professionals with relatively high incomes), there were in absolute numbers many more young people in the top third of mental ability who were lower class in origins than were to be found amongst the upper classes. ${ }^{4}$ Yet, among the Grade 12 high mental ability students covered in the survey, 82 per cent of those of higher socio-economic status (SES) expected to continue to Grade 13 (and thence, in most cases on to university) whilst only 59 per cent of the lower class students in the same ability range expected to get that far (for most of the rest, the choice was immediate employment or entry to a C.A.A.T.). This percentage -59 per cent - contrasts vividly with the 73 per cent of the low mental ability, high SES students who expected to stay in school until after Grade 13. The finding of relatively low educational expectations amongst intelligent, low-class youth, is underlined by John Buttrick's conclusion that about one-half of Metro Toronto's academically talented youngsters do not actually reach Grade 13, and that most of the academically apt students who do not reach this level come from low income families (Buttrick: 4 and 95).

2. Porter et. al. assume that high mental ability students have the capacity for university work although they may not have the necessary grades to be admitted, and they may not be particularly interested in further education (op. cit.: 64). There is, therefore, something of 'a slip twixt cup and lip' between mental ability test scores and actual educational performance and interests: and indeed we know, from the Porter study that one very good reason why substantial numbers of bright lower-class youth did not expect to remain in school until after Grade 13 was that they had already enrolled in one of the four year academic, commercial or technical high school programmes which lead either on to employment or to further education at a C.A.A.T. (but not, like the five year programme, immediately on to a university). The choice of specific programmes of study by high school students is certainly linked to their levels of mental ability - for example, in the Porter study, the proportions of students of high mental ability who were enrolled 
in the four year programmes ranged from just 4 per cent of those of high SES down to 23 per cent of those of low SES, yet amongst student of low mental ability, the proportion for the two SES categories were 28 per cent and 62 per cent respectively - but, as this same example shows, SES is also very important in determining programme choice (op. cit.: 74). Similar findings, based on national data, were obtained by Breton (1970: 24).

Since mental ability is linked to choice of programme of study, it follows that the socalled "academic stratification system" of the high school (that is, its various academic programmes and tracks) has, as one of its functions, the establishment of some kind of balance between mental ability and educational ambition; that is, the brighter students tend to enter programmes of study which, because of their linkage to university admission, encourage high educational ambition and achievement, and the less bright students tend to enter employment or community college-linked programmes which may lead them to accept more modest educational goals. However, because the academic stratification system of the high school is also, in some measure, a social stratification system, this function of the "regulation of ambition" may well extend to dampening down the educational aspirations of those bright lower class students who tend, in relatively large numbers, to enrol in programmes which do not qualify them for university admission. This point is made strongly by Porter et. al. who refer to the impact of the academic stratification system of the high school on lower class Ontario youth as "disastrous" because it appears to dampen considerably their educational ambitions (op. cit.: 74). Not unrelated, Anisef et. al. point to the fact that, in Ontario, students living in small towns and rural areas are far more likely than those living in large towns and cities to choose technical and commercial over academic high school streams (a factor which may help to explain their low university participation) whilst females are more likely than males to enter academic and commercial streams, but are negligibly represented in technical programmes (op. cit. : 59).

3. Whilst there is abundant evidence of a linkage between socio-economic status, choice of type of high school programme and decisions pertaining to post-secondary education (i.e. whether to go on to university or college and, if so, which type of postsecondary institution), there is also some evidence that the impact of socio-economic status is attenuated once the student actually enters a post-secondary institution. For example, in Pascal and Kanowitch's review of studies of student withdrawals from Canadian universities, the conclusions of the limited research carried out on the relationship between socio-economic background and student withdrawal are ambiguous to say the least, but - if anything - they suggest that students from low income areas may be less likely to withdraw than those from higher income areas (1979: 27). More concretely, the Anisef study indicates that the status level of first and subsequent occupations obtained by the respondents in their Ontario sample (status, that is, as determined by such factors as income and occupational prestige) was largely determined by the post-secondary credentials achieved. Thus, in the author's words, "we showed that high socio-economic status facilitates university attendance. However, once university graduation has been achieved, whether an individual has a higher or lower SES background is of little further consequence: university graduates in general tend to obtain high-status and well-paying occupations" (op. cit.: 226).

The suggestion that, in Ontario at least, students' socio-economic origins may no longer have much direct impact on educational and occupational opportunities once post-secondary education is actually underway, raises some interesting questions about 
the nature of the linkages between higher education and social stratification in English Canada. First of all, one might well wonder whether the same attenuation of the impact of socio-economic status would be found in provinces which admit students to university from Grade 11 or Grade 12, because Grade 13 in Ontario acts as an additional academic barrier to university education: that is, one which presumably will be surmounted only by those lower-class students who have sufficient ability and motivation to have overcome the limitations imposed by their social origins. Secondly, even if it were to be found that the Ontario conclusions are not paralleled in all other provinces, it is still probable that the relatively academically selective nature of university education in this country (compared, for example, with the wide range of public and private degree-granting institutions in the U.S. catering to a wide range of ability levels) does not allow so easily for the intrusion of socio-economic influences into academic performance at the university level. More specifically, when a university or college maintains an 'open door' or liberal admissions policy ard specifically attempts to cater - as some American institutions have done to the academic needs of lower class, minority group youth with limited academic credentials, the impact of socio-economic origins on academic performance and ultimately upon occupational opportunities, is likely to be quite apparent.

Third, and related to the above comments, there is no clear evidence in English Canada of a clearly defined institutional prestige hierarchy of Canadian universities which is linked to the class structure of the wider society. Thus, it is generally recognized that the private and expensive American Ivy League institutions draw a high proportion of their students from wealthy homes, and that attendance at these institutions constitutes a symbol of prestige (and a source of useful contacts) which helps to maintain, and strengthen, the class position of their graduates. Again, some prestigious state universities such as Michigan and Berkeley, are high above the bulk of state "mass" institutions in terms of resources and esteem (see Mayes, 1977). In Canada, given the essentially public nature of the universities and the predominantly regional and provincial character of their clienteles, an equivalent national hierarchy has not developed. However, one does recognize that in a province with a substantial number of universities (e.g. Ontario), some are generally regarded by students and faculty as having a more substantial academic reputation than others.

Finally, and notwithstanding the foregoing observations, it is very likely that in Canada, as is the case in other western countries, the decision to enter particular programmes and faculties within a university is linked to socio-economic background: for example, medical students tend to be recruited from well-off professional families (not least because there is a substantial measure of self-recruitment to the medical profession), and students in educational faculties have tended to traditionally come from somewhat less well-off homes. It follows, therefore, that the existence of a "social stratification" system within the university may well be linked to recruitment into professional and managerial occupations which, although all generally classified as 'high status', do actually differ considerably in terms of income and prestige. This is a topic which is worth exploring further. So also is the nature of the interlinkages which have been shown to exist between attendance at one of a number of exclusive fee-paying private schools, graduation from one of a small number of older Canadian universities - notably, McGill and the University of Toronto - and ultimate membership in one of Canada's major elite groups (see notably, Clement, 1975).

4. Whilst the influence of socio-economic status appears to be attenuated at the postsecondary level, the influence of gender is apparent at all stages of the educational system 
and also in the sphere of occupational choice. For example, as already noted, girls tend to be found in academic and commercial high school programmes but rarely in technical programmes. Again, amongst the respondents to the Statistics Canada Survey of Graduates in 1976 ( a survey which excluded Quebec), about twice as many women as men graduated with one or two-year college diplomas whilst, on the other side of the coin, at the master's degree level, female recipients were outnumbered by males 2 to 1 , and at the doctoral level the ratio was 5:1 (Devereaux and Rechnitzer, 1980). Finally, whilst the numbers of women and men who had received bachelor's or first professional degrees was nearly equal - an indication of the substantially increased participation of women in undergraduate study during the past two decades - women college and university graduates tended to be employed in a relatively narrow range of occupations (notably, the health field, teaching and clerical work) and earned, on average, about 15 per cent less than males in the same occupational field who had the same level of education and were in full-time employment ( $o$ cit., passim). In reviewing similar income-differentials data derived from the Highly Qualified Manpower Survey of 1973, Bill Ahamad et. al. suggested that these differentials may be due to any, or all, of three sets of factors: interruption of women's careers for family reasons, the likelihood that, in a few occupational fields though not generally - women may work shorter hours than men, and finally employer discrimination (op. cit. : 109). They did not, however, analyse the discrete impact of these factors in any detail.

\section{Social Causes and Sociologists' Reactions}

The foregoing emphasis upon inequalities in educational and occupational opportunities might strike some readers as misplaced. After all, instead of emphasizing the fact that the offspring of well-educated, professional parents have a disproportionately high participation in university education, I could have noted that, about 20 per cent of full-time undergraduate students come from families where the father has obtained only an elementary education. Similarly, rather than pointing to the relatively low educational expectations of many bright lower class children, I might have stressed that about 35 per cent of the mentally able, lower class Grade 12 students in the Porter et al. survey expected to go on to university after completing high school studies (Porter: 69). Why then have I not placed my emphasis on the extent to which there is opportunity for intergenerational social mobility through the educational system in English Canada? The reason lies in the fact that the traditional ideology of North America., supported quite strongly by many functionalist writers, has always emphasized the theme of an "open society", whereas recent sociological research in the field has been at pains to demonstrate that English Canadian society is far from being a meritocracy open without stint to the most talented. The die is not entirely cast for lower class children, or for women, but it is evident that ascribed factors do strongly influence patterns of motivation and educational and occupational choices (see Anisef: 363). More concretely, since our society still pays homage to the concept of equality of educational opportunity, it is of some importance to seek to understand the nature of the social factors which act as barriers to the higher education of many talented young people.

To pursue this issue of social causation, I should mention that a number of Anglophone sociologists have undertaken research into the causes of social class differences in educational motivation and behaviour. In particular, much attention has been given to the formation of educational aspirations, and sociologists such as Trevor Williams (1972) and 
Sid Gilbert (1977) have explored the complex interrelationships which exist between young people's aspirations, their social origins and such variables as scholastic achievement, self-concept of ability and programme of study. 5 Similarly, Raymond Breton's nation-wide survey of the career decisions of Canadian youth (op. cit.) demonstrates that, even when mental ability rank is controlled, lower status Anglophone students tend to consider themselves less intelligent than those from more advantaged families, and have a weaker sense of personal control over their futures (Breton, op. cit.: 143-144). Moreover - and I find this to be particularly significant - when lower status students do have an attitude of fatalism and anxiety about the future, this attitude appears to make them far less certain about planning to complete high school than is the case with higher status students who feel the same way about the future (Breton: 147-148). It is probable, therefore, that parental pressures and expectations function to keep higher status students in the school system, even though they may not have very positive views of their future prospects, whereas such pressures and expectations are less likely to be present in the lower class home.

In the view of many sociologists, the types of educational attitudes outlined above are deeply embedded in the class structure of a socially and economically unequal society. Hence, since these attitudes are not likely to be amenable to significant change through traditional policies of educational reform, it follows that the achievement of greater equality of educational opportunity must rest less on further educational reforms than on attempts to achieve a greater measure of equality in the wider society of which the educational system is a part (or greater "equality of condition" as it is sometimes referred to). Indeed, an extreme position held by some neo-Marxists is that most educational reforms are placebos offered by the capitalist class in order to prevent the rise of social discontent - and hence such reforms are deemed useless (or worse), since the only real solution to educational inequality is seen to lie in the overthrow of capitalism in favour of a more egalitarian social order. However, a less extreme position is that educational reforms should proceed, provided that it is recognized that the pursuit of greater equality of educational opportunity is made much more difficult by the existence of substantial inequality of condition and provided also that (since there is little evidence that the expansion of secondary and post-secondary opportunities during the past twenty years has significantly reduced the unequal distribution of material resources or the proportion of poor people in Canadian society), it is understood that greater equality of educational opportunity cannot be viewed as a general solution to the problems of the socially disadvantaged.

Further to the above, I should mention that the late John Porter, to whom sociology in this country owes so much, came to a general acceptance of this less extreme position over the course of twenty years of research devoted mainly to exploring various aspects of inequality in Canadian society. Thus, although his earlier educational writings tended to fit rather well into the general 'human capital-functionalist' perspectives of the period, the book Does Money Matter? (first published in 1973) makes clear that Porter and his colleagues had come to believe that equality in education could not be truly achieved without moving toward a more equal society, one which they felt would have to be brought about through greatly reduced income differentials or a much more progressive income $\operatorname{tax}(o p$ cit. : 152). At the same time, however, since it is one of the major themes of the book that the substantial gap between the educational aspirations of lower class Ontario youth and their lower, and presumably more realistic, expectations were partly to be 
explained by the existence of financial barriers which prevented their access to university, the authors offered a series of suggestions for policy reform, including the founding of the Ontario Student Aid Programme more firmly upon the principles of accessibility, equality and viability (op. cit.: 155). More recently though, in two lectures which he delivered at York University in 1977, and which were devoted to the theme of "Education, Equality and the Just Society", Porter ended by concluding that "so far educational reforms of the twentieth century have failed in their task of promoting equality of either condition or opportunity..." (Porter, 1979: 278-279): a hard conclusion for a scholar who had devoted so much previous effort to formulating liberal proposals for educational change. His reassessment of his own earlier position was, nonetheless, fairly typical of the declining optimism displayed amongst sociologists for what used to be called "the promise of educational reform".

\section{Suggestions for Further Research on Stratification and Higher Education}

As I have already mentioned, there is a general need for the replication in other provinces and regions of the major studies on socio-economic status and educational opportunities already carried out in Ontario. However, some other fruitful areas for research both in Ontario and elsewhere would include first, the study of socio-economic background, gender and patterns of programme choice within institutions of higher learning, and the study of alternative modes of post-secondary education with particular reference to the roles of community colleges both as channels for the facilitation of inter-generational social mobility and as agencies for the strengthening and legitimation of existing class barriers. Again, the evidence from the Anisef study on rural-urban differences in educational opportunity, leads me to suggest that more attention should be given to the part which "feeder colleges" and distance learning institutions such as the Open Learning Institute of British Columbia (which now draws the greater part of its students from outside the Vancouver area) may play in facilitating access to higher learning for rural youth and adults.

In addition to the above suggestions for research in the field, there are three other areas ripe for investigation which might be appropriately mentioned at this point:-

First of all, the last decade has seen a substantial relative decline in the willingness of governments to fund post-secondary education: a retreat from the "God of Human Capital" which was so important in the stimulation of post-secondary expansion during the 1960's. Very often, however, when queried about these financial cutbacks, provincial government spokesmen claim that the public is no longer prepared to grant post-secondary education a place of high priority amongst spending alternatives: indeed, that the public has lost some faith in the value of higher learning. The problem is, of course, that statements of this kind are difficult to confirm or refute because political scientists and sociologists have not paid very much attention (and should certainly pay more) to the nature and formation of public attitudes towards post-secondary education in English Canada. A notable exception to this neglect is, however, the study carried out by Andrew Hughes for the Atlantic Institute of Education (1979) which surveyed the attitudes toward post-secondary education of 1,163 adult Maritimers. ${ }^{6}$ This survey reveals that most people in the Maritime region have a generally favourable attitude towards post-secondary education, and would not wish to see public expenditure reduced at any educational level.

Secondly, as noted earlier, there is some evidence that numbers of young men have decided that the decline in the economic returns to university education do not compen- 
sate adequately for three or four years of earnings foregone. More specifically, based on the 18.21 age group, the participation rate of Canadian males in full-time undergraduate education declined from 21.3 per cent to 19.0 per cent between 1973-74 and 1978-79, whilst the rate for women rose from 14.2 per cent to 16.0 per cent. At the non-university, post-secondary level, participation rates for males were the same in 1978.79 as five years previously (12.8 per cent based on 18-21 age group), but the rate for women again rose, from 11.5 per cent to 13.7 per cent (Statistics Canada, 1980, Table 2). It seems probable, therefore, (in the absence of a compensatory increase in part-time enrolments) that numbers of young men who would have gone on to university if they had graduated from high school during the optimistic days of the 1960's no longer do so. However, what are the social and intellectual characteristics of these "stay outs"? Some evidence from the United States where it has recently been estimated that between 1971 and 1976 about 250,000 males were "lost" to the universities and colleges, suggests a drop in the high college participation rates of white males from affluent families, and a larger drop in the already smaller participation rates of white males from families of moderate means (Geiger, 1980).

Finally, since the topic is closely related to the themes of social stratification and power (as well as to sociological research in the field of formal organizations), I should point to the very limited English language research on the social characteristics and attitudes of those individuals who form the Boards of Trustees and Boards of Governors of our post-secondary institutions. I am aware, of course, of A.S. Konrad's study of community college trustees in Alberta, British Columbia and selected Quebec institutions (1977) which shows them to be overwhelmingly male, professional, financially well-off and usually members of the political party which is in power provincially. Also, in a 1974 survey of the Boards of Governors of eight Ontario universities, J. Barkans and Norene Pupo found that about 40 per cent of these governors were members of the Canadian economic elite, holding directorships in large Canadian companies (1978). These research findings give radical sociologists the kind of ammunition that they think is needed to "prove" that Canadian higher education, big business and politics are all in the same ideological bed together. However, although there is some evidence that trustees of the public and private universities in the United States are not only overwhelmingly white, protestant and late middle-aged but also highly conservative in their attitudes to such matters as the screening of campus speakers and the rights of faculty to public bargaining (see Simon, 1980), we need far more thorough and detailed Canadian research on the nature of our "governing academic elites" before we can judge whether or not these governors are the most appropriate persons to make relevant decisions of the kind which will enable universities and colleges to adapt swiftly to the rapidly changing social environment of which they form a part.

\section{THE STUDY OF HIGHER EDUCATIONAL ORGANIZATIONS}

\section{Formal Organizational Research}

In contrast to the English language sociological research on higher education and social stratification, the sociological study of educational organizations, including universities and colleges, has hardly begun in this country. Indeed, in the area of formal organizations - namely, the study of bureaucracy, control systems, authority structures and goals in English Canadian institutions of higher education - the kind of research which gives some 
attention to sociological theory and concepts is negligible in quantity. One notable oasis in this desert is the organizational over-view by Canadian sociologists Edward Harvey and Jos. Lennards, of what they call "The University in Crisis" (1973). Another is the study of S. Dasgupta, et. al. on campus and community attitudes toward the University of Prince Edward Island and its goals (1975). Finally, mention should be made of the doctoral thesis by Alberta sociologist R.S. Pannu which focusses upon a case study of institutional change in university governance with special reference to faculty participation and conflict in the early organizational development of the University of Lethbridge (1973). Pannu's major theoretical thrust, also utilized in a more general framework by James Hartmann $(1974,1977)$, is based upon the argument that attempts to understand institutional change in the university setting should concentrate less on problems of efficient goal attainment, technical rationality and organizational survival and more upon struggles for power of various competing groups of administrators, faculty members and students. In the light of the internecine faculty struggles which appear to have accompanied the creation of the University of Lethbridge (and which Pannu outlines in substantial detail), I am not really surprised that his dissertation has, so far, remained unpublished!

In Hartmann's view, there are two major contending models of university organization: the epistemological and the political (1974, passim). The former emphasizes the pursuit of truth and knowledge and tends to appear in the idealistic preambles of university five-year development plans. ${ }^{7}$ The latter reflects the presence of conflict and power struggles, and is far more commonly the model used by sociologists such as Pannu. These two models cannot, Hartmann believes be reconciled because they are, in a sense, alternate languages, either one of which is appropriate to some situations but inappropriate to others" (op. cit. : 27). However, in a subsequent paper (1977), he focusses centrally upon change and conflict in the university, and notes that there are many forces at work in institutions of higher learning which contribute to the generation of conflict. Amongst these forces are, first, those associated with student protest; secondly, those associated with tensions which lie in the contrast between the demands of professional personnel for individual autonomy and academic freedom, on the one hand, and the need for organizational efficiency, control and accountability, on the other; third, departmental and faculty disputes about the distribution of scarce resources. This latter type of conflict is one which is likely to be associated with contemporary low growth rates in higher education linked to increased financial constraints. Indeed, J. McCallum Vickers, writing from the standpoint of a C.A.U.T. official, has explored some of the organizational conflicts and tensions which may emerge from the battle for scarce resources (1979, notably 73). More generally, the eminent American sociologist Martin Trow has written an important paper which examines the institutional implications of low growth rates for higher education (1976).

It is hopefully evident from the above brief review that I would tend to emphasize the importance of initiating sociological research which focusses upon institutional change and organizational conflict in English Canadian higher education, with particular consideration being given to those potentials for conflict (although also indeed for cooperation) which has arisen as a result of the relative "hard times" which have fallen on universities and colleges during the past decade. In the United States, this issue has - as we have seen - engaged the interest of sociologists of the calibre of Martin Trow. Also, one can point to the earlier major study by J. Victor Baldridge, Power and Conflict in the University: Research in the Sociology of Complex Organizations (1970). However, lest it should be 
believed that my view of organizational research in the Canadian university and college is totally dominated by the sociological "blinkers" of power, confrontation, and conflict, let me further draw attention to the important overview of decisive issues in higher education which, based upon national studies of the higher education systems of twleve countries including Canada, was published by the International Council for Educational Development in 1978 (Clark Kerr, et. al., 1978). This volume, although much of it is not explicitly sociological, focusses upon such themes as co-ordination, innovation and flexibility within hgiher educational systems and organizations: and, therefore, acts as a useful counter-balance to the rather dominant conflict perspective.

\section{STUDENT ATTITUDES, VALUES AND BEHAVIOUR}

Burton Clark's overview of the sociology of higher education in the United States (op. cit.: 1973), provides a useful shorthand account of some of the major American studies on student attitudes, values and behaviour which had been carried out during the previous couple of decades. At the time he was writing, the waves of articles and books dealing with the campus unrest of the 1960's were just beginning to subside. However, whilst many of these students protest studies were, as Clark notes, "long on ideology and short on research" (op. cit.: 6), there were other studies based on a more solid research foundation which attempted to look closely at campus life in its non-violent, and non-militant, manifestations; and notably at types of undergraduate sub-cultures and students' orientation towards making the academic grade. Amongst the most important of these latter studies, one may point to the study by Howard Becker and others of student attitudes toward academic work and achievement at the University of Kansas (1968), and the series of essays on the social psychology of higher education edited by Kenneth Feldman (1972). Across the Atlantic, Joan Abbott's monumental study of the influence of social class factors on the family life, social relations and attitudes of students at three British universities was published in 1971. It was probably not coincidental, of course, that so many of these solid sociological studies were undertaken during the period of university expansion and student unrest: at a time, that is, when professors and administrators as well as research investigators became interested, for quite partial reasons, to ascertain "how students tick".

One gains the impression that the past few years of slow growth in higher education, coupled perhaps with the reduction of protest on campuses in western nations, has led to some parallel reduction in research interest in student attitudes and behaviour. How ever, this impression does not have much relevance to sociological research in this field in English Canada for the very good reason that, as is the case with sociological research into the organization of higher education, even the post-secondary expansion of the 1960's stimulated no substantial flow of research on Canadian campus life or student attitudes. In 1973, for example, Edward Harvey and Jos Lennards devoted the large part of a review essay on "The University as an Agent of Attitude Change" to commenting upon relevant American studies on the effectiveness of the university as a teacher of liberal-arts values. Since corresponding studies in this country could not (and cannot) be found, the authors offered some general observations on the reasons why the conclusions of the U.S. research might not be applicable to Ontario; and also numerous suggestions for appropriate lines of study on student and faculty attitudes in the provincial universities (Harvey and Lennards, 1973, passim). Sad to say, their suggestions for research do 
not appear to have been yet taken up by fellow sociologists, but their observations on some differences between American and Ontario universities were rather similar to those made earlier in this paper. Thus, they noted that Ontario universities lacked the wide spread of institutional prestige differences which influence the recruitment patterns of both faculty and students in American higher education (and hence which lead to wide variations in the collective attitudes of students in different institutional settings). Similarly, the province does not contain the range of specialized, single-purpose organizations which characterize university education south of the border (e.g. liberal-arts colleges, junior colleges, professional schools), but rather has focussed upon the establishment and maintenance of multi-purpose institutions (op. cit.: 42-43).

From the foregoing observation, the reader might be led to believe that studies on campus life and student attitudes in Anglo-Canada are tabula rasa. Well, almost - but not quite. There are, fortunately, a small number of doctoral theses and institutional studies which throw some light upon the academic aspects of student life and, to a lesser extent, upon student social participation. Perhaps the most valuable of these is the doctoral thesis of Gordon P. Meyers which explored student strategies for adaptation in the academic sphere at the University of Calgary (Univesity of Toronto, Ph.D., 1979). Meyers based his participant observation and survey questionnaire research fairly closely upon Howard Becker et. al.'s University of Kansas study (op. cit.), and came to some rather similar conclusions. In a nutshell, he found that amongst arts and science undergraduates at the University of Calgary there exists a dominant student perspective characterized by a major emphasis upon the achievement of good grades (rather than learning per se), and a corresponding emphasis upon patterns of behaviour which are appropriate to the attainment of this credentialist goal. Thus, Calgary undergraduates' general interaction with faculty can be characterized as "low risk" behaviour: they tend to be polite and reserved in class, to undertake actions which will make them agreeable to the instructors (but not to become very friendly which tends to be perceived as "cheating"), and to withdraw, when they can, from courses in which there is a high risk of failure or a low grade (Meyers, passim). In short, in contrast to the humanistic model of the university as a place where students may become deeply involved in their surrounding academic and social environment, the Meyers study provides a somewhat depressing dose of social reality: "... I did not get the idea", he notes, "that students had plans for development beyond career matching and maintaining a low risk, convenient undergraduate experience" (op. cit.: 327). And again, "The long term goals of the students, in addition to career preparation, are undertaken in tandem with non-academic goals - particularly a conformity to behaviour of typical middle-class norms such as maintaining pleasant relations, and seeking low-risk ventures. Students also seek a balance, or at least a private side of life, that may have very little to do with being a student. The desire to have this, for the majority of students, suggests that the academic life is not engaging in either time or energy, nor do the non-academic activities of the university seem important experiences" (op. cit. : 324).

The evidence from Meyers' study that university students find various academic strategies to cope with their work is supported by Oswald Hall and Richard Carlton's smallscale survey of high school students going on to university in the Ontario community of "Alberttown" (1977). These authors found, for example, that the students whom they interviewed at "Alberttown University" discovered a system of shortcuts and devices which they used to reduce the amount of reading and writing they undertook (for example, 
they "borrowed" other students' reports and rarely bothered to proof-read papers) so that ". . . in the tug-of-war that goes on between them and the instructors they seem to have more success in retaining the standards of the secondary school than the instructors have in implementing the official standards of the university" (Hall and Carlton: 240-241). More generally, although students have presumably always found ways of coping with heavy workloads, one is bound to wonder whether the apparent lack of intellectual stimulation which many students associate with the university experience may not be related, in part, to the high school grade inflation which has tended to occur since the late 1960's (and which presumably has allowed numbers of not-so-bright students into the university system), and also to changes in academic requirements and expectations within the universities and colleges themselves. On the impact of high school grade inflation, the four volume study by J.T. Davis and others of Factors Influencing Student Enrolment, Performance and Experience at York University (1977) provides evidence that there has been a steady decline in the ability of York University undergraduates who have attained over 70 per cent in their Grade 13 matriculation scores to achieve grades of ' $B$ ' or higher in their university courses (Volume 4 , passim). On the impact of changing academic requirements and expectations within the university, both Meyers' Calgary study and the York study make reference to a tendency towards more liberal grading of students by university staff (and that despite the perceived decline in the academic abilities of the York students) and this tendency should, perhaps, be seen as one aspect of the phenomenon that University of Toronto sociologist John Lee has referred to as "failsafe education" (1976). Failsafe education is characterized by institutional attempts to eliminate failure from the educational career - by low university entrance requirements, a plethora of non-compulsory courses, allowance for last-minute withdrawal of failing students from courses, and course re-enrolment in order to at tain a higher grade - and also by "cheating" as a common student activity. For example, Lee suggests that the writing of an identical paper for two or three courses is common amongst university students (op. cit.: 44), and Meyers' survey indicates that a large proportion of the arts and science undergraduates at the University of Calgary did not, in actuality, regard this action of "doubling" as cheating (op. cit.: 238).

Thus, the few studies of the academic strategies which occur amongst university and college students in the English-language universities do throw some light on one major aspect of campus life. However, it would now be valuable to undertake one or more relatively large-scale research projects which compare, for example, student attitudes and behaviour and patterns of faculty-student interaction, in a variety of contrasting insti. tutional settings. More specifically, large-scale commuter universities such as York or Calgary do - as the earlier comment from Meyers' study indicates - tend to be characterized by the relatively low participation of their students in social activities on campus (for evidence of low student participation in social activities at York, see Jansen, 1972). And again, one of the major findings of most freshmen/senior attitude studies is that student attitude change at university tends to be lower at commuter universities than at universities with large numbers of students living in residence (Harvey and Lennards, op. cit.: 54). These findings suggest that studies of the commuter universities should be matched or paired with studies of those universities such as Queen's or Trent which, within the physical environment of the small city setting, have substantial numbers of their students living in. Harvey and Lennards are, as $I$ have suggested, probably correct in arguing that substantial variations between the student clientele of different universities are far less in Canada 
than in the United States: but one assumes, nevertheless, that some variations do indeed exist.

One final word on another issue which the literature on student activities has brought to my attention: namely, the existence of the high level of student part-time employment during term time and its impact upon academic performance. In the Post-Secondary Student Survey of 1974-1975 it was found that 28 per cent of full-time students were engaged in part-time employment activities during term time (op. cit.: 54), and in the Davis et. al. survey of full-time students at York University, 53 per cent of the undergraduate respondents from the Arts Faculty stated that they held part-time jobs during term time (Volume 3: 31-34). It is difficult to know whether the majority of the students who take part-time jobs during the academic year are motivated primarily by financial considerations or, rather, whether they work because of a desire, at least in the case of off-campus employment, to remove themselves from the 'Ivory Tower' of the campus in order to experience the world outside (an explanation which would be in line with Meyers' comments about their "private side of life"). In any event, it would clearly be interesting to look further into this phenomenon of part-time employment, and seek to understand the motivations behind it. By the same token, whilst a recent American review of several surveys on student employment indicates that it does not adversely affect college grade point averages, there is some U.S. evidence that off-campus jobs, especially if engaged in for twenty hours a wek or more, do have a negative impact on students' persistence in their programmes (Hood and Maplethorpe, 1980: 68). Similarly, in the York survey, a substantial minority of the respondents holding part-time jobs claimed that part-time employment had a "very negative effect" on their schoolwork, and 65 per cent mentioned some negative effect (Volume 3: 31-32).

\section{THE ACADEMIC PROFESSION}

As much of our previous discussion has indicated, university-based sociologists in English Canada do not seem very eager to look within their own backyards. This is evident in the case of research on higher education organizations and student sub-cultures, and patently apparent in the neglected research field of higher education as a profession.

It is true that organizational research may incorporate research on the roles of academics within universities and colleges - for example, the strain between professional and bureaucratic orientations, and the tension common to the roles of professional people in complex organizations - and, indeed, the cited study by R.S. Pannu (op. cit.) is closely concerned with this theme. However, such basic lines. of sociological research as the career patterns of academics, their status and styles of life, their teaching and research orientations, their political persuasions, their attitudes toward post-secondary expansion or contraction: none of these have, with the notable exception of the issue of job mobility opportunities, received any significant attention from the sociological community.

Much of what is known about the Canadian professoriate was summed up in a twentypage paper which Janet Scarfe and.Edward Sheffield published in 1977 (in Altbach, 1977). This paper points to the existence of a limited number of studies on such themes as the proportionate under representation of women in university posts (and particularly at the top), the controversy over the "Canadianization" of the professoriate, the extent of the involvement of professors in political matters and, probably most significant of all, the aging of university and college faculties as a result of the stabilization in hiring. However, 
since the Scarfe-Sheffield paper was published, Max von Zur-Muehlen (1979 and 1980) has provided some useful statistical insights into the implications of the changing agestructure of the Canadian academic community for such matters as rates of promotion and the future viability of academic pension plans. In a more sociological vein, Linda Moffat has studied occupational mobility amongst Ontario university teachers through the use of large-scale questionnaire survey techniques (1980).

In my view, Moffat's research represents probably the first major attempt by a sociologist in English Canada to take a hard empirical look at a major aspect of academic life during a period of economic retrenchment. Her survey which consisted of a questionnaire sent out to a large stratified sample of faculty members who had either left, or entered, full-term employment in an Ontario university during the years 1974 and 1976, reveals that occupational mobility within the Ontario university system is far from being static; but that, nonetheless, a high proportion of the movement of university teachers is concentrated at the bottom of the system (hence the title of her report Room at the Bottom) as new Ph.D's are offered a series of short-term non-tenure stream appointments beyond which they cannot progress (op. cit. : 190-191). This feature of academic life, well known to those of us who are substantially engaged in departmental administration as being a major cause of low morale and high anxiety amongst junior colleagues, is a depressing consequence both of limited movement at the top and of the tendency for the universities to try to ease their economic ills through the creation of a pool of short-term contract labour. It means, in essence, that "an academic career" no longer exists for many young scholars though "a job" might. Ironically, however, it would appear from Moffat's study that even "a job" at the bottom of the academic hierarchy is relatively less accessible for Canadian-trained Ph.D.'s than those with foreign doctorates. Thus, in summarizing some of her research conclusions, Moffat observes that ". . . holders of foreign degrees are more likely to be given permanent contracts in Ontario universities than are holders of Canadian degrees except Toronto degrees and ... Canadian origins confer no advantage to the incumbent, even when he or she holds a foreign degree. If Canadian Ph.D.'s were not evaluated so negatively there would be no shortage of jobs" (op. cit.: 187). In her view, despite the recent official emphasis upon the hiring of Canadians, the "old boy" personal hiring networks between Canadian and foreign universities still persist.

Clearly, the aging of the Canadian professoriate, the creation of a pool of "academic circuit riders" at the bottom of the system, the obvious decline in the morale of many university and college teachers during the current relative hard times; all these topics would constitute major research areas for the sociologist. Possibly what we require is someone with the combined abilities of A.H. Halsey and Martin Trow to undertake a study of Canadian academics which would correspond to the monumental sociological study, The British Academics, which these two scholars co-authored and published in 1971. However, when Halsey and Trow began to think about their book in 1963, they were interested to learn how academics in Britain might adapt themselves and their institutions to a period of expansion and redefinition of higher education (Halsey and Trow, op. cit.: 25). If we were to change the word "expansion" to "contraction" in order to fit the mood of the 1980's, this question would make a good starting point for Canadian research. 


\section{CONCLUDING REMARKS}

Despite the substantial length of this overview, I am aware of a number of important topics in the sociology of higher education which have received some attention from Anglophone sociologists but which have not been given serious consideration here. One such topic is the controversial field of higher education and Canadianization, including the various responses to the Symons Report. Another is the universities and colleges' social role in the field of adult and continuing education which, although the subject of some sociological research (including my own study in Ontario, op cit.), still offers much scope for sociological investigation. A third important field lies in the interlinkage between race, ethnicity and participation in higher education - an interlinkage which has featured prominently in the American literature, but which (with the possible exception of the Anglophone-Francophone division) has received rather limited attention from social scientists in English Canada. However, on this latter theme, one should certainly make passing mention of two of the published background studies prepared by the Commission on Post-Secondary Education in Ontario, one of which dealt with the post-secondary educational opportunities of the Ontario Francophone population (D'Costa, 1971) and the other with the post-secondary opportunities of the Ontario Indian population (Environics Research Group; 1971). Furthermore, we have some evidence from the York University survey to the effect that between 1969 and 1976 there was a very substantial proportionate increase in the numbers of Canadian students of non-British ethnic origin - and particularly of non-European origin - entering York (Davis, Volume 3: 3-4). This finding suggests that, in the large metropolitan centres, the universities are increasingly becoming the route through which the first and second generation non-British immigrants of the past three decades are attempting to move into the upper levels of Canadian occupational and class structure.

As one of a couple of parting shots, let me stress what has been implicit in much of the foregoing review - namely, the value of a developmental, comparative perspective in the sociological study of higher education. It is probable that, in comparison with such countries as Britain and the U.S.A., the institutionalization of higher education in Canada has followed a distinct pattern and that the repercussions of past are still with us. ${ }^{8}$ Secondly, I would like to suggest a number of reasons why, with the exception of the field of higher education and stratification, English language sociological research on higher education in this country is not very advanced. One reason is probably that the entrenchment of sociology in the Canadian universities only took place after the Second World War, and by the time that there was a substantial body of sociologists employed within English Canadian institutions of higher learning - that is, by the late 1960's - the universities and colleges were already losing their erstwhile high profile with governments and publics, and did not appear to offer the same opportunities for research, nor the research dollars, as such trendy Canadian themes as ethnic relations, multiculturalism and, more recently, social gerontology. Another, more general, reason is that Canadian sociological research on higher education is subject to the same limitations on institutional and financial support which exist here for any kind of research on higher education: for example, with the possible exception of the A.U.C.C., there are a lack of supporting organizations equivalent to the College Entrance Examination Board, The Ford Foundation and The 
Carnegie Foundation, all of which have played vital roles in the sponsorship of American research in the field. Third, there is the old bugbear of provincial control of education which, because of the nature of provincial government funding for educational research, tends to encourage some research within provinces, but not much between them. Finally, as some of my earlier comments indicate, I do not think that many Canadian sociologists consider the institutions within which most of them work to be appropriate - or 'safe' - topics for study. Furthermore, since it is very rare for them to have received a specific graduate education in the "sociology of higher education" field or to have worked in a setting where groups of sociologists devote their time to higher education research, it might be said that many of them do not have a "mental set" which inclines them to work in the field.

\section{FOOTNOTES}

1. Thus, the review does not include reference to English-language studies of higher education in Quebec unless these are part of a national study.

2. This suspicion is reasonably founded upon the fact that sociologists in Quebec are far more likely than those in English Canada to be employed by government: for example, in 1969, 23 per cent of Francophone sociologists belonging to the Canadian Sociology and Anthropology Association reported employment by government compared with only 3 per cent of Anglophone sociologists (Forcese and Richer, 1975: 461). Differences between sociology and sociologists in Quebec and English Canada are well reviewed in the Forcese and Richer paper.

3. Parts of this section constitute a modified version of some observations contained in my recent paper "Education, Class and Power in Canada" (1980).

4. The social class categories referred to here are based upon the Blishen occupational scale. Students whose fathers are employed mainly in professional and managerial occupations are classified by Porter et. al. as "high social class" or "high socio-economic status"; those whose fathers are second level managerial, lower paid professionals, salesmen, skilled workers, etc., are classified as "medium social class" or "medium socio-economic status"; those whose fathers are semi-skilled and unskilled manual workers and farmers are classified as "low social class" or "low socio-economic status" (Porter, 1979: 32-33). The Blishen occupational scale correlates highly with income level and occupational prestige.

5. Their studies tend to stress the importance of family influence in helping to form young people's educational aspirations and expectations.

6. Also very relevant are the three surveys of public attitudes toward education in Ontario carried out in 1978,1979 and 1980 by D.W. Livingstone and D.J. Hart of the Ontario Institute for Studies in Education. For example, the most recent of these studies indicates that the vast majority of the respondents would like to see total educational expenditures at least keep up with inflation, and that there may have been some decline over time in the numbers of Ontario residents opposed to any increases at all in educational spending (Livingstone and Hart, 1980: 11). However, a high proportion of respondents - 58 per cent of the total, but only 42 per cent of those with university qualifications - would like to see the Ontario universities become "more job-related" than they are at present (op. cit.: 31 ).

7. The example is mine, not Hartmann's.

8. I am indebted to Jos Lennards for pointing out to me the importance of this approach.

\section{REFERENCES}

Abbott, J., Student Life in a Class Society, Pergamon Press, 1971.

Ahamad, B., et. al., Degree Holders in Canada, Ottawa: Secretary of State, 1979

Anisef, P., Paasche, J.G., and Turrittin, A.H., Is The Die Cast?: Educational Achievements and Work Destinations of Ontario Youth, Toronto: Ministry of Education and Ministry of Colleges and Universities, 1980. This is the latest of a series of reports on the 1973 survey group. 
Baldridge, V.J., Power and Conflict in the University: Research in the Sociology of Complex Organizations, New York: John Wiley, 1970

Barkans, J. and Pupo, N., "Canadian Universities and the Economic Order" in R.W. Nelsen and D.A. Nock (eds.), Reading, Writing and Riches: Education and the Socio-Economic Order in North America, Kitchener: Between the Lines, 1978

Becker, H.S., Geer, B., and Hughes, E.C., Making the Grade: The Academic Side of University Life, New York: Wiley, 1968

Bowles, S. and Gintis, H., Schooling in Capitalist America, New York: Basic Books, 1976

Breton, R., Social and Academic Factors in the Career Decisions of Canadian Youth. Ottawa: Department of Manpower and Immirgration, 1972

Breton, R., "Academic Stratification in Secondary Schools and the Educational Plans of Students", The Canadian Review of Sociology and Anthropology, Volume 7, No. 1 February 1970.

Buttrick, J., Who Goes To University From Toronto, Toronto: Ontario Economic Council Working Paper No. 1/77, 1977

Card, B.Y., "The State of Sociology of Education in Canada - A Further Look", Canadian Journal of Education, Volume 1, 1976

Clark, B.R., "Development of the Sociology of Higher Education", Sociology of Education, Volume 46, No. 1,1973

Clement, W., The Canadian Corporate Elite, Toronto: McClelland and Stewart, 1975

Connor, D.M. and Curtis, J.E., Directory of Sociologists and Anthropologists in Canada, Second Edition, Montreal: Canadian Sociology and Anthropology Association, 1973

D'Costa, R.B., Post-Secondary Opportunities for the Ontario Francophone Population, background study to the Commission on Post-Secondary Education in Ontario, Toronto: Ministry of Government Services, 1971

Dasgup ta, S., et. al., Attitudes Toward University Goals: A Study of Campus and Community Attitudes Toward the University of Prince Edward Island and Its Goals, Charlottetown: U.P.E.I., 1975

Davis, J.T., Jansen, C., and Olsen, T.W., Factors Influencing Student Enrolment, Performance and Experience at York University, 4 Volumes, Toronto: Office of Research Administration, York University, 1977

Decore, A.M., "Sociology of Education in Canada: A Review Essay", The Journal of Educational Thought, Volume II, No. 3, 1977

Dennison, J.D., et. al., The Impact of Community College: A Study of the College Concept in British Columbia, Vancouver: British Columbia Research, 1975.

Devereaux, M.A. and Rechnitzer, E., Higher Education - Hired?, Ottawa: Statistics Canada and Labour Canada Women's Bureau, 1980

Environics Research Group, Post-Secondary Opportunity for the Ontario Indian Population, background study to the Commission on Post-Secondary Education in Ontario, Toronto: Ministry of Government Services, 1971

Feldman, K.A. (ed.), College and Student: Selected Readings in the Social Psychology of Higher Education, New York: Pergamon Press, 1972

Forcese, D. and Richer, S., Issues in Canadian Society: An Introduction to Sociology, Toronto: Prentice Hall, 1975

Geiger, R.L., "The Changing Demand for Higher Education in the Seventies: Adaptations in Three National Systems", Higher Education, Volume 9, No. 3, May 1980

Gilbert, S., "The Selection of Educational Aspirations" in R.A. Carlton, et. al. (eds.), Education, Change and Society: A Sociology of Canadian Education, Toronto: Gage, 1977

Government of Canada, Department of the Secretary of State, Some Characteristics of Post-Secondary Students in Canada, Ottawa: Education Support Branch, Secretary of State, 1976

Hall, O. and Carlton, R., Basic Skills at School and Work, Ontario: Ontario Economic Council, Occasional Paper 1, 1977

Halsey, A.H. and Trow, M., The British Academics, London: Faber and Faber, 1971

Hartmann, J.B., "Change and Conflict in the University", The Journal of Educational Thought, Volume 11 , No. 1,1977 
Hartmann, J.B., "Complementary Models of University Organization", The Journal of Educational Thought, Volume 8, No. 1, 1974

Harvey, E., "Accessibility to Post-Secondary Education - Some Gains, Some Losses", University Affairs, October 1977(a)

Harvey, E., Opportunity and Choice: Changes in the Canadian Post-Secondary Student Population, 1969-1975, 1977(b), (unpublished manuscript)

Harvey, E. and Lennards, J.L., "The University as an Agent of Attitude Change" and "The University in Crisis: An Organizational Analysis", both in Harvey and Lennards, Key Issues in Higher Education, Toronto: O.I.S.E., 1973

Hood, A.B. and Maplethorpe, C.K., "Bestow, Lend or Employ: What Difference Does It Make?" in J.B. Henry (ed.), New Directions for Institutional Research: The Impact of Student Financial Aid on Institutions, Jossey Boss, 1980

Hughes, A.S., Public Attitudes Toward Post-Secondary Education in the Maritime Provinces, Atlantic Institute of Education, 1979, pp. 64

Hurn, C., The Limits and Possibilities of Schooling, Boston: Allyn and Bacon, 1978

Jansen, C., Housing, Transport and Social Participation at York University, 2 Volumes, Toronto: Institute for Behavioural Research, York University, 1972

Kerr, C., et. al., 12 Systems of Higher Education: 6 Decisive Issues, New York: International Council for Educational Development, 1978

Konrad, A.S., "A Profile of Community College Trustees", Canadian Journal of Education, Volume 2, No. 2, 1977

Lee, J.A., "Failsafe Education", The Canadian Journal of Higher Education, Volume VI, No. 1, 1976

Livingstone, D.W. and Hart, D.J., Public Attitudes Toward Education in Ontario, 1980: Third O.I.S.E. Survey, Toronto: O.I.S.E., 1981

Lockhart, A., "Future Failure: The Unanticipated Consequences of Educational Planning" in R. Pike and E. Zureik (eds.), Socialization and Values in Canadian Society, Volume II, Toronto: McClelland and Stewart, 1975

Mayes, S.B., "The Increasing Stratification of Higher Education: Ideology and Consequences", The Journal of Educational Thought, Volume 11, No. 18, 1977

McCallum Vickers, J., "The Changing Roles of Professors and University Administrators" in A. Gregor and K. Wilson (eds.), Issues in Higher Education, Monograph in Education 1, Winnipeg: University of Manitoba, 1979

Meyers, G.P., Student Strategies for Adaptation in the Academic Arena: A Description of Collective Behaviour at One University, unpublished doctoral dissertation, University of Toronto, 1979

Moffat, L.K., Room at the Bottom: Job Mobility Opportunities for Ontario Academics in the MidSeventies, Toronto: Ministry of Colleges and Universities, 1980

Pannu, R.S., Collegial Bureaucracy: A Study of Power and Conflict in Academic Self-Governance in a New Canadian University, unpublished doctoral dissertation, University of Alberta, 1973

Pascal, C. and Kanowitch, S., Student Withdrawals from Canadian Universities: A Study of Studies, Toronto: O.I.S.E., 1979

Pike, R.M., "Education, Class and Power in Canada" in R.J. Ossenberg (ed.), Power and Change in Canada, Toronto: McClelland and Stewart, 1980

Pike, R.M., "Part-Time Undergraduate Studies in Ontario" in R.M. Pike et. al., Innovation in Access to Higher Education, New York: I.C.E.D., 1978

Pike, R.M., Who Doesn't Get To University - And Why, Ottawa: Runge Press, 1970

Porter, J., The Measure of Canadian Society, Toronto: Gage, 1979

Porter, J., The Vertical Mosaic, Toronto: University of Toronto Press, 1965

Porter, M.R., Porter, J., and Blishen, B.R., Does Money Matter? Prospects for Higher Education in Ontario, Toronto: Carleton Library, 1979

Russell, C.N., et. al., Post-Secondary Plans, Aspirations and Profile Characteristics of Grade 12 Students in Manitoba, 1977-78, Winnipeg: Province of Manitoba, 1978

Scarfe, J. and Sheffield, E., "Notes on the Canadian Professoriate" in P.G. Altbach (ed.), Comparative Perspectives on the Academic Profession, New York: Praeger, 1977 
Schechter, S., "Capitalism, Class and Educational Reform in Canada" in L. Panitch (ed.), The Canadian State: Political Economy and Political Power, Toronto: University of Toronto Press, 1977

Simon, F., "Student Activism: When Will It Return?", The Journal of Educational Thought, Volume 14, No. 1, April 1980

Statistics Canada, Education in Canada: A Statistical Review for 1978-79, Ottawa: Statistics Canada, 1980

Trow, M., "The Implication of Low Growth Rates for Higher Education", Higher Education, Volume 5,1976

von Zur-Muehlen, M., "The Age Structure of Canadian University Teachers and Its Implications", Interchange, Volume 10, No. 3, 1979-80

von Zur-Muehlen, M. and Belliveau, J., Three Decades of Full-Time Canadian University Teachers: A Statistical Portrait, report prepared for the tenth anniversary meeting of the Canadian Society for the Study of Higher Education, May 10, 1980

Williams, T.H., "Educational Aspirations: Longitudinal Evidence on their Development in Canadian Youth", Sociology of Education, Volume 45, Spring, 1972 